\title{
Temperature-dependent sex determination in the Kemp's ridley sea turtle: effects of incubation temperatures on sex ratios
}

\author{
Anne Marie LeBlanc ${ }^{1, *}$, Thane Wibbels ${ }^{1}$, Donna Shaver $^{2}$, Jennifer Shelby Walker $^{2}$ \\ ${ }^{1}$ Department of Biology, The University of Alabama at Birmingham, Birmingham, Alabama 35294-1170, USA \\ ${ }^{2}$ Padre Island National Seashore, National Park Service, Corpus Christi, Texas 78480-1300, USA
}

\begin{abstract}
This study provides the most comprehensive evaluation to date of the temperature range that produces mixed sex ratios as well as the temperature that produces a 1:1 sex ratio (denoted 1:1 temperature in the following) in the Kemp's ridley sea turtle Lepidochelys kempii. We analyzed temperature data from Padre Island National Seashore (PAIS), Texas (USA). Using 2006 to 2008 PAIS sex ratio data sorted by mean temperature, which fluctuated minimally in this study, we found a $1: 1$ temperature of $30.0^{\circ} \mathrm{C}$ utilizing the Hill distribution model. The upper limit of the temperature range that was estimated to produce mixed sex ratios was $32.5^{\circ} \mathrm{C}_{i}$ the lower end could not be determined. These values are in the upper range of those reported for other sea turtle species, except the olive ridley. The Kemp's ridley temperature-dependent sex determination parameters described here can be used to predict sex ratios from nests with known incubation temperatures in order to help manage the recovery of this species.
\end{abstract}

KEY WORDS: Sex ratio - Sea turtle - Kemp's ridley - Sex determination - Temperature · Conservation

Resale or republication not permitted without written consent of the publisher

\section{INTRODUCTION}

In 1947, Andres Herrera recorded a short film with aerial views of an arribada, or group nesting, estimated to include approximately $40000 \mathrm{Kemp}$ 's ridleys Lepidochelys kempii nesting at Rancho Nuevo, Mexico, on a single day (Carr 1963, Hildebrand 1963). From the 1940s through the mid-1980s, the number of nesting Kemp's ridleys drastically declined, almost reaching extinction (Carr 1963, Hildebrand 1963, Ross et al. 1989, Dodd \& Byles 1991, Márquez-M. 1994). This endangered population is now gradually recovering (Márquez-M. et al. 2001), in large part due to a bi-national collaborative program between Mexico and the USA that began in 1978 to protect nesting females on the beach and offshore, as well as to protect nests and hatchlings. In
Mexico, nests and hatchlings are protected by moving eggs to hatcheries (i.e. 'egg corrals'). To further protect the species from extinction, eggs were brought from Mexico to Texas in order to establish a secondary nesting colony within the known nesting range of the Kemp's ridley. The number of natural nests occurring in Texas is increasing, mirroring the increase in Mexico. Nests on most Texas beaches are protected from predators and other disturbances by moving them to protected locations, either to egg corrals on the beach or to an incubation laboratory at Padre Island National Seashore (PAIS).

Like all sea turtles, the Kemp's ridley has temperature-dependent sex determination (TSD; Aguilar 1987, Shaver et al. 1988), and therefore, moving eggs to alternate incubation locations has the potential to produce different sex ratios than would occur if left in 
situ. Previous studies using constant incubation temperatures indicate that sea turtles possess a male: female (M:F) pattern of TSD whereby warm temperatures produce females and cooler temperatures produce males (reviewed by Wibbels 2003). A transitional range of temperatures (TRT) exists between these temperatures, where sex ratios shift from all male to all female. Within the TRT is a 'pivotal temperature' estimated to produce a 1:1 sex ratio (Mrosovsky \& Pieau 1991).

Previous laboratory studies have defined the term 'pivotal temperature' to indicate the constant incubation temperature that produces a 1:1 sex ratio. In the study, we intentionally used incubation temperature regimes with small daily fluctuations, in an attempt to mimic natural fluctuations in the beach sand temperature (Shaver 2005). Therefore, for the purpose of the current study, we use a new term (i.e. '1:1 temperature') to indicate the average of the daily fluctuating temperatures that produces a 1:1 sex ratio. Similarly, TRT has been defined as the range of constant temperatures that results in the production of both sexes (Mrosovsky \& Pieau 1991). We did not use constant temperatures; therefore, the temperature range that produces mixed sex ratios will be given.

Correlating incubation temperatures with hatchling sex ratios produced by an endangered population with TSD is imperative for studying the population and estimating species recovery timelines. Coyne \& Landry (2007) provided a model for assessing the potential effect of sex ratio on population recovery. Using their model, a sex ratio of $75 \%$ female would yield a $271 \%$ increase in predicted nests after $50 \mathrm{yr}$, in comparison to a 1:1 sex ratio (assuming that males do not become a limiting factor). Incubation temperatures and the resulting hatchling sex ratios have been monitored for many years at PAIS and Rancho Nuevo, Mexico (Shaver et al. 1988, Shaver 2005, 2007, 2008, 2009, Wibbels 2007, Eich 2009). The current and future sex ratios produced in the recovery program for the Kemp's ridley could be monitored and, if necessary, managed (Wibbels 2007, Eich 2009).

Results by Merchant-Larios et al. (1997), and supported in subsequent studies (Shaver 2005, 2007, 2008, 2009, Eich 2009), suggest that mean incubation temperatures during the middle third of the incubation period can be an accurate predictor of sex. Here, we analyzed incubation temperature data from PAIS from 2006 to 2008 to evaluate hatchling sex ratios and the 1:1 temperature in Kemp's ridley sea turtles using an advanced statistical model developed for evaluating TSD (Girondot 1999, Godfrey et al. 2003).
The analysis in this study characterizes TSD in the Kemp's ridley sea turtle and provides information for accurately predicting sex ratios from nests of known incubation temperatures. The results of this study can be used to further optimize management strategies, relative to hatchling sex ratios, for the Critically Endangered Kemp's ridley sea turtle.

\section{MATERIALS AND METHODS}

Temperature data were collected for nests in the incubation facility at PAIS between 2006 and 2008. Nests were packed into 20.81 Styrofoam ${ }^{\circledR}$ boxes using moist sand from the egg chamber. To prevent overheating, clutches with more than 100 eggs were split into 2 Styrofoam ${ }^{\circledR}$ incubation boxes. A copper constantan thermocouple probe was placed in the center of the egg mass in every incubation box. Temperature probes were constructed using copper-constantan-copper, 3-prong connectors and insulated thermocouple wire. The nest boxes were transported to the incubation facility where incubation temperatures are closely monitored and controlled. The temperature monitoring probes were connected to a data acquisition system which collected and recorded the temperature of the incubating eggs once per hour. Accuracy of the temperature readings from this system varied no more than $0.3^{\circ} \mathrm{C}$, when compared using a certified thermometer. The incubation facility building measures approximately $7.3 \times 7.3 \mathrm{~m}$ and is an enclosed structure with fiber cement siding, exterior plank, insulation, and pine wood interior. Eggs that were not viable and any dead hatchlings were removed after hatching occurred and dissected as described in the following section. Samples were collected for histology of the gonads. The incubation temperature and sex ratio data were published in yearly reports by PAIS (Shaver 2007, 2008, 2009). These data were entered into the TSD program (Girondot 1999, Godfrey et al. 2003) to find the best fit model (see 'Data analysis' below).

\section{Determining sex of hatchlings and late-stage embryos}

The use of gonadal histology is considered the most accurate method for sexing individual hatchlings (Yntema \& Mrosovsky 1980, Wibbels 2003), as hatchling sea turtles cannot be sexed using external characteristics. In the current study, unhatched dead embryos and dead hatchlings were removed from 
incubation boxes after the live hatchlings had emerged. Due to the endangered status of the Kemp's ridley, hatchlings were not sacrificed for this sex ratio study. Tissue samples were dissected so that the gonadal region was exposed, then stored in $10 \%$ buffered formalin.

Histological techniques (Humason 1972) were used to examine gonadal tissue from each hatchling; specifically, the structure of the medullary and cortical regions of the gonads was examined to determine sex (Merchant-Larios 1999, Wibbels et al. 1999, based on Yntema \& Mrosovsky 1980). Tissue sample data were compared to mean nest temperature during the middle third of the incubation period. Some samples were not used in the analysis, as their sex could not be determined due to tissue degradation.

\section{Data analysis}

Temperature data were analyzed using JMP statistical software version 4.0.4 (SAS). Incubation period was defined as the time when the eggs began incubation until hatching. Mean $( \pm \mathrm{SD}$ ) temperatures were calculated for each day during the entire incubation period for each nest. Temperatures were aggregated for the entire incubation period. The incubation period was divided into thirds. The mean temperature from the middle third of the entire incubation period was approximated to be equal to the critical period, or thermo-sensitive period, for the loggerhead turtle (Yntema \& Mrosovsky 1982) and the olive ridley turtle (Merchant-Larios et al. 1997). For the purposes of the current study, the mean temperature from the middle third of the entire incubation period was approximated to be the temperature which affected the sex determination pathway. During the middle third of incubation, when we approximated that sex determination occurs, daily temperatures within the incubation boxes fluctuated a minimal $0.7 \pm 0.3^{\circ} \mathrm{C}$, which has been shown to not significantly impact the effective mean incubation temperature (Georges et al. 1994). The mean temperature during the middle third of incubation for incubation boxes used in this study was $31.1 \pm 0.6^{\circ} \mathrm{C}$ (during the middle third of incubation, hourly temperatures for all nests monitored from 2006 to 2008 ranged from 28.5 to $33.8^{\circ} \mathrm{C}$, mean difference $=2.2 \pm 0.5^{\circ} \mathrm{C}$ ). Temperatures from 61 individual incubation boxes were included in these analyses for 2006; the mean temperature during the middle third of incubation for these incubation boxes in 2006 was $31.5 \pm 0.2^{\circ} \mathrm{C}$ (hourly temperatures during the middle third of incubation ranged from 29.4 to $33.3^{\circ} \mathrm{C}$, mean difference $=2.2 \pm 0.4^{\circ} \mathrm{C}$; Table 1). During 2007, temperatures from 27 individual boxes were included; the mean temperature during the middle third of incubation for these incubation boxes in 2007 was 30.6 $\pm 0.3^{\circ} \mathrm{C}$ (hourly temperatures during the middle third of incubation ranged from 28.6 to $33.1^{\circ} \mathrm{C}$, mean difference $=2.3 \pm 0.5^{\circ} \mathrm{C}$; Table 1 ). Temperatures from 22 individual boxes were included in the analyses for 2008; the mean temperature during the middle third of incubation for these incubation boxes in 2008 was $30.4 \pm 0.2^{\circ} \mathrm{C}$ (hourly temperatures during the middle third of incubation ranged from 28.5 to $32.7^{\circ} \mathrm{C}$, mean difference $=2.0 \pm 0.6^{\circ} \mathrm{C}$; Table 1 ). The overall emergence success for those boxes by year was: 2006, $70.8 \%$; 2007, 76.6\%; and 2008, $86.0 \%$.

The data set was evaluated using the TSD program developed by Girondot (1999) and Godfrey et al. (2003) and available at www.ese.u-psud.fr/epc/ conservation/TSD/index.html. The program estimates an Akaike Information Criterion (AIC) value, pivotal temperature $(P)$, the curve representing the relationship between sex ratio and temperature during the transition from masculinizing to feminizing temperature $(S)$, and an asymmetrical shape parameter $(K)$. As described by Godfrey et al. (2003), the AIC is a measure that rewards models for good fit. The alpha risk, or Type I error, was also measured for the fit of the equation using the parameters of the program, with 1000 replicates; a p value $>0.05$ indicates that the fit cannot be rejected. The sums of male and female hatchlings per mean middle third temperature reading (in tenths of a degree Celcius) were used for the analyses. Only mean middle third temperature readings where at least 10 gonad samples were analyzed to sex were used in the analysis. A total of 110 separate incubation groups (boxes) were monitored for temperature and provided histology results; 20 of these were clutches of eggs that were split into 2 incubation boxes each. Therefore, 90 clutches were utilized for this study. An uncertainty of $0.3^{\circ} \mathrm{C}$ was assigned in order to account for the temperature precision of the data acquisition system.

Table 1. Lepidochelys kempii. Summary of mean $( \pm \mathrm{SD})$ temperatures $\left({ }^{\circ} \mathrm{C}\right)$ during the middle third of the incubation period. Data are from Padre Island National Seashore (Texas, USA), 2006 to $2008 ; n=$ number of incubation boxes

\begin{tabular}{|ccccc|}
\hline Year & $\mathrm{n}$ & $\begin{array}{c}\text { Mean } \\
\text { temperature }\end{array}$ & $\begin{array}{c}\text { Hourly temp. } \\
\text { range }\end{array}$ & $\begin{array}{c}\text { Mean daily } \\
\text { difference }\end{array}$ \\
\hline 2006 & 61 & $31.5 \pm 0.2$ & $29.4-33.3$ & $2.2 \pm 0.4$ \\
2007 & 27 & $30.6 \pm 0.3$ & $28.6-33.1$ & $2.3 \pm 0.5$ \\
2008 & 22 & $30.4 \pm 0.2$ & $28.5-32.7$ & $2.0 \pm 0.6$ \\
\hline
\end{tabular}




\section{RESULTS}

Sex ratios from dead late-stage embryos and dead hatchlings from PAIS, 2006 to 2008, were determined using histology (Shaver 2007, 2008, 2009; Table 2). A female bias was produced each year.

The data from PAIS 2006 to 2008 (Shaver 2007, 2008, 2009) included 90 clutches with 18 different mean middle third incubation temperatures (Table 3). Temperatures ranged from 30.1 to $32.2^{\circ} \mathrm{C}$.

Using PAIS 2006 to 2008 sex ratio data sorted by temperature, the TSD modeling program estimated the 1:1 temperature using the Hill equation to be 30.0 $\pm 0.0017^{\circ} \mathrm{C}(\mathrm{df}=16 ; \mathrm{AIC}=67.52 \pm 0.0011)$. The test of power resulted in $K=0$, and the alpha risk value was $<0.001$ after 1000 replications. The upper limit of the

Table 2. Lepidochelys kempii. Summary of sex ratio data based on gonadal histology from Padre Island National Seashore (PAIS) 2006-2008. Data from late-stage embryos and hatchlings found dead in the nest are summarized on a nest by nest basis in yearly reports from PAIS (Shaver 2007,

2008, 2009). Table includes all individuals analyzed

Year Hatchlings (n) Females (n) Males (n) Female (\%)

\begin{tabular}{lllll}
\hline 2006 & 651 & 561 & 90 & 86 \\
2007 & 205 & 161 & 44 & 79 \\
2008 & 268 & 181 & 87 & 68 \\
\hline
\end{tabular}

Table 3. Lepidochelys kempii. Histology-based sex ratio data of hatchlings and late-stage embryos from Padre Island National Seashore 2006-2008 (Shaver 2007, 2008, 2009) per mean ( \pm mean SD) middle third incubation period temperature; only those temperatures where at least 10 gonad samples were analyzed are included

\begin{tabular}{|lcccc|}
\hline $\begin{array}{l}\text { Temperature } \\
\left({ }^{\circ} \mathrm{C}\right)\end{array}$ & $\begin{array}{c}\text { Incubation } \\
\text { boxes }(\mathrm{n})\end{array}$ & $\begin{array}{c}\text { Female } \\
(\mathrm{n})\end{array}$ & $\begin{array}{c}\text { Male } \\
(\mathrm{n})\end{array}$ & $\begin{array}{c}\text { Freq. of } \\
\text { females }\end{array}$ \\
\hline $30.1 \pm 0.4$ & 4 & 3 & 9 & 0.25 \\
$30.2 \pm 0.5$ & 7 & 30 & 6 & 0.83 \\
$30.3 \pm 0.4$ & 7 & 12 & 2 & 0.86 \\
$30.4 \pm 0.5$ & 6 & 7 & 4 & 0.64 \\
$30.6 \pm 0.6$ & 5 & 15 & 4 & 0.79 \\
$30.7 \pm 0.6$ & 10 & 53 & 10 & 0.84 \\
$30.8 \pm 0.6$ & 6 & 8 & 4 & 0.67 \\
$30.9 \pm 0.4$ & 3 & 11 & 4 & 0.73 \\
$31.0 \pm 0.4$ & 3 & 10 & 8 & 0.56 \\
$31.3 \pm 0.5$ & 8 & 35 & 7 & 0.83 \\
$31.4 \pm 0.4$ & 9 & 49 & 6 & 0.89 \\
$31.5 \pm 0.4$ & 12 & 80 & 5 & 0.94 \\
$31.6 \pm 0.4$ & 14 & 122 & 7 & 0.95 \\
$31.7 \pm 0.4$ & 5 & 42 & 2 & 0.95 \\
$31.8 \pm 0.6$ & 3 & 22 & 0 & 1.00 \\
$31.9 \pm 0.5$ & 5 & 20 & 2 & 0.91 \\
$32.0 \pm 0.6$ & 2 & 12 & 0 & 1.00 \\
$32.2 \pm 0.7$ & 1 & 10 & 1 & 0.91 \\
\hline
\end{tabular}

temperature range that produced a mixed sex ratio was $32.5^{\circ} \mathrm{C}$; the lower end could not be determined due to a lack of data regarding cooler temperatures (Fig. 1).

\section{DISCUSSION}

Kemp's ridleys appear to possess a male:female $(\mathrm{M}: \mathrm{F})$ pattern of sex determination in which cool temperatures produce males, and warmer temperatures produce females (reviewed by Wibbels 2007). The data suggest that the temperature range that produces a mixed sex ratio extends from approximately 29 (or lower) to $32.5^{\circ} \mathrm{C}$. Although 2 other TSD patterns have been described in reptiles with TSD (Ewert et al. 1994), the M:F pattern appears to be a basic characteristic of sea turtle sex determination (Wibbels 2007). Historically, pivotal temperatures have been estimated from constant incubation temperature studies. In the current study, the data set was from a facility with controlled temperature regimes with intentional small daily fluctuations in temperature to mimic natural fluctuations in beach sand temperatures. Therefore, as indicated in the 'Intrduction', we use the term '1:1 temperature' in contrast to pivotal temperature. The data indicated a 1:1 temperature of $30.0^{\circ} \mathrm{C}$ when utilizing the Hill model from the TSD program (Girondot 1999, Godfrey et al. 2003). A pivotal temperature of $30.2^{\circ} \mathrm{C}$ was previously reported for the Kemp's ridley using linear

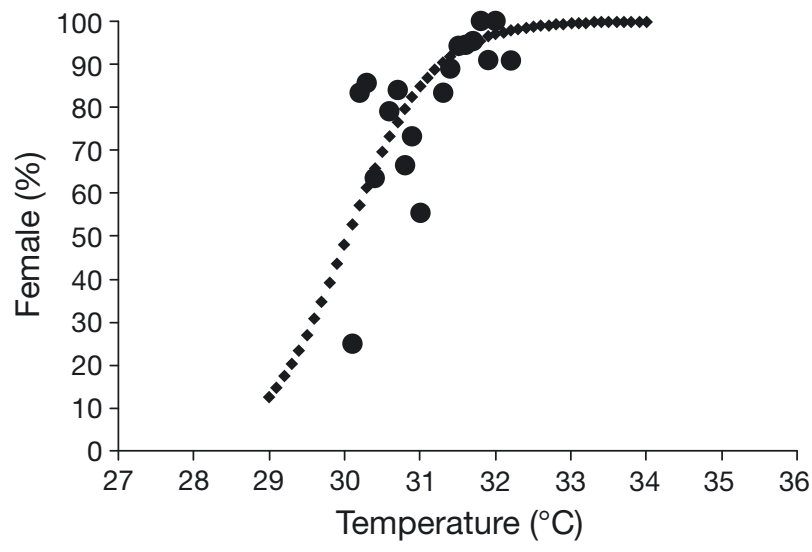

Fig. 1. Lepidochelys kempii. Diamonds: average sex ratio (\% female) versus average temperature in the middle third of the incubation period, from the Hill model as determined by the temperature-dependent sex determination (TSD) program, based on Padre Island National Seashore (PAIS) 2006 to 2008 data. Circles: histology-based sex ratio data of hatchlings and late-stage embryos from PAIS 2006 to 2008 (Shaver 2007, 2008, 2009); each circle represents the average sex ratio ( $\%$ female) for a single incubation temperature 
regression analysis (Shaver et al. 1988). Our 1:1 temperature estimate of $30.0^{\circ} \mathrm{C}$ for the Kemp's ridley is within the range of typical pivotal temperatures estimated for other sea turtles in the past (approximately 29 to $30^{\circ} \mathrm{C}$, Wibbels 2003), but this is in the upper portion of the range of pivotal temperatures reported for sea turtles, which have been reported as high as $30.5^{\circ} \mathrm{C}$ for olive ridleys nesting in Playa Nancite, Costa Rica (Wibbels et al. 1998).

The TSD program was unable to estimate the low range of temperatures that would produce a mixed sex ratio, but the results indicate that temperatures of approximately $32.5^{\circ} \mathrm{C}$ or higher will produce $100 \%$ females. In general, TSD appears similar in all sea turtle species. They all exhibit a similar M:F pattern of sex determination, pivotal temperatures range from approximately 29 to $31^{\circ} \mathrm{C}$, and the TRT normally ranges from approximately 27 to $32^{\circ} \mathrm{C}$ (Wibbels 2003). These similarities may reflect the evolution of pivotal temperatures and TRTs that match the thermal environment of the nesting beach. It also suggests that nesting beach thermal environments may be relatively similar among sea turtle species. Such similarities could be due to a variety of factors. For example, successful embryonic development may require a specific range of temperatures. Further, the seasonal timing of nesting may be dependent upon environmental temperature (Mendonça 1987), and thus help select for nesting beach temperatures that fall within the range of pivotal temperatures and TRTs.

Sex ratios can be estimated from the TSD program parameters reviewed above, using the Hill equation. The Hill equation and parameters suggested for hatchling Kemp's ridley sex ratio predictions were:

$$
\operatorname{sr}(t)=\frac{1}{1+\mathrm{e}^{(1 / S)(\ln (P+K)-\ln (t+K))}}
$$

where $\operatorname{sr}(t)$ is sex ratio at a specific temperature $(t)$, $S=-0.01834, P=30.03809$, and $K=0.1$.

The current study may have been limited by a number of factors. First, due to the endangered status of the Kemp's ridley, sacrificing hatchlings or embryos for experimental purposes was not permitted. This limited the sample sizes that were available for analysis. The test of the power to distinguish between a symmetric and an asymmetric TSD curve indicated that the sample size was low for the PAIS 2006 to 2008 data set, even though it included 622 hatchlings from 90 nests which spanned 18 mean middle third incubation temperatures. Second, the ability of the model equation to find the best fit possible was limited by a scarcity of temperatures that produced all males or male biases. Third, the hatch- lings and late-stage embryos used for these analyses were not a randomly sacrificed sample; they were dead individuals that were collected from nests after the live hatchlings had emerged. Therefore, a potential bias for differential sex mortality exists. A previous study did not find differential sex mortality in loggerhead sea turtle nests using small samples (A. M. LeBlanc unpublished data); however, questions still surround this issue (Mrosovsky et al. 2009). We also note that the temperatures in the facility were closely managed for the conservation goals of producing a female-dominated sex ratio and high hatching success, guided by years of research and input from the bi-national Kemp's Ridley Sea Turtle Working Group (Shaver 2005). From a scientific viewpoint, future studies including larger sample sizes are needed to adequately resolve this issue. Lastly, a cautionary note is necessary: the intention of the sex ratio prediction equation given is to help predict general sex ratios. The pivotal temperature and TRT represent averages for the population (Dodd et al. 2006); thus, sex ratios for individual nests may not precisely match what is predicted by temperature using this model. However, the use of this model provides the most accurate estimates available.

We used standardized statistical methods to optimally model a large data set of sex ratios in the Kemp's ridley. The results provide a basis for predicting Kemp's ridley sex ratios based on incubation temperatures. These findings could provide a method for accurately estimating sex ratios produced in the Kemp's Ridley Recovery Program at Rancho Nuevo and in Texas.

Acknowledgements. We acknowledge the University of Alabama at Birmingham Histology Laboratory students for their efforts to embed, section, stain, and determine sex of each gonad. Additionally, we thank National Park Service staff and other personnel who assisted in finding the nests, collecting the eggs, collecting and analyzing the temperature data, and providing gonad samples. The National Park Service obtained the following permits for this work: US Fish and Wildlife Service Endangered Species Permit TE-840727; Texas Parks and Wildlife Department Scientific Permit SPR0190-122.

\section{LITERATURE CITED}

Aguilar HR (1987) Influencia de la temperatura de incubación sobre la determinación del sexo y la duración del period de incubación en la tortuga lora (Lepidochelys kempi, Garman, 1880). Instituto Politecnico Nacional Mexico, México DF

Carr A (1963) Panspecific reproductive convergence in Lepidochelys kempi. Ergeb Biol 26:298-303 
Coyne M, Landry AM Jr (2007) Population sex ratio and its impact on population models. In: Plotkin PT (ed) Biology and conservation of ridley sea turtles. The Johns Hopkins University Press, Baltimore, MD, p 167-189

Dodd CK Jr, Byles R (1991) The status of loggerhead, Caretta caretta; Kemp's ridley, Lepidochelys kempi; and green, Chelonia mydas, sea turtles in US waters: a consideration. Mar Fish Rev 53:30-31

Dodd KL, Murdock C, Wibbels T (2006) Interclutch variation in sex ratios produced at pivotal temperature in the redeared slider, a turtle with temperature-dependent sex determination. J Herpetol 40:544-549

Eich AML (2009) Evolutionary and conservation implications of sex determination and hatchling depredation in Kemp's ridley sea turtles. PhD dissertation, The University of Alabama at Birmingham

Ewert MA, Jackson DR, Nelson CE (1994) Patterns of temperature-dependent sex determination in turtles. J Exp Zool 270:3-15

Georges A, Limpus C, Stoutjesdijk R (1994) Hatchling sex in the marine turtle Caretta caretta is determined by proportion of development at a temperature, not daily duration of exposure. J Exp Zool 270:432-444

Girondot M (1999) Statistical description of temperaturedependent sex determination using maximum likelihood. Evol Ecol Res 1:479-486

Godfrey MH, Delmas V, Girondot M (2003) Assessment of patterns of temperature-dependent sex determination using maximum likelihood model selection. Ecoscience $10: 265-272$

Hildebrand HH (1963) Hallazgo del area de anidacion de la tortuga marina 'lora' Lepidochelys kempi (Garman), en la costa occidental del Golfo de Mexico (Rept. Chel.). Ciencia (Mex City) 22:105-112

Humason GL (1972) Animal tissue techniques. WH Freeman, San Francisco, CA

Márquez-M. R (1994) Synopsis of biological data on the Kemp's ridley turtle, Lepidochelys kempi (Garman, 1880). Tech Mem NMFS-SEFSC 343. US Department of Commerce, NOAA, NMFS, Miami, FL

Márquez-M. R, Burchfield P, Carrasco MA, Jimenez C and others (2001) Update on the Kemp's ridley nesting in Mexico. Mar Turtle Newsl 92:2-4

Mendonça MT (1987) Photothermal effects on the ovarian cycle of the musk turtle, Sternotherus odoratus. Herpetologica 43:82-90

Merchant-Larios J (1999) Determining hatchling sex. In: Eckert KL, Bjorndal KA, Abreu-Grobois FA, Donnelly M (eds) Research and management techniques for the conservation of sea turtles. IUCN/SSC Marine Turtle Specialist Group Publication No. 4, p 130-135

Merchant-Larios H, Ruiz-Ramirez S, Moreno-Mendoza N, Marmolejo-Valencia A (1997) Correlation among thermosensitive period, estradiol response, and gonad differentiation in the sea turtle Lepidochelys olivacea. Gen Comp Endocrinol 107:373-385

Editorial responsibility: Matthew Godfrey, Beaufort, North Carolina, USA
Mrosovsky N, Pieau C (1991) Transitional range of temperature, pivotal temperatures and thermosensitive stages for sex determination in reptiles. Amphib-Reptilia 12: 169-179

Mrosovsky N, Kamel SJ, Diez CE, van Dam RP (2009) Methods of estimating natural sex ratios of sea turtles from incubation temperatures and laboratory data. Endang Species Res 8:147-155

Ross JP, Beavers SC, Mundell D, Airth-Kindree M (1989) The status of Kemp's ridley. Center for Marine Conservation, Washington, DC

Shaver DJ (2005) Analysis of the Kemp's ridley imprinting and headstart project at Padre Island National Seashore, Texas, 1978-88, with subsequent Kemp's ridley nesting and stranding records on the Texas coast. Chelonian Conserv Biol 4:846-859

Shaver DJ (2007) Padre Island National Seashore, Texas Sea Turtle Nesting and Stranding 2006 Report. US Department of the Interior, National Park Service, Corpus Christi, TX

Shaver DJ (2008) Padre Island National Seashore, Texas Sea Turtle Nesting and Stranding 2007 Report. US Department of the Interior, National Park Service, Corpus Christi, TX

Shaver DJ (2009) Padre Island National Seashore, Texas Sea Turtle Nesting and Stranding 2008 Report. US Department of the Interior, National Park Service, Corpus Christi, TX

Shaver DJ, Owens DW, Chaney AH, Caillouet CW Jr, Burchfield P, Marquez-M R (1988) Styrofoam box and beach temperatures in relation to incubation and sex ratios of Kemp's ridley sea turtles. In: Schroeder BA (comp) Proc 8th Annu Conf Sea Turtle Biol Conserv, Fort Fisher, NC. Tech Memo NMFS-SEFC-214, US Department of Commerce, NOAA, NMFS, Miami, FL, p 103-108

Wibbels $\mathrm{T}$ (2003) Critical approaches to sex determination in sea turtles. In: Lutz PL, Musick JA, Wyneken J (eds) The biology of sea turtles. CRC Press LLC, Boca Raton, FL, p 103-134

Wibbels T (2007) Sex determination and sex ratios in ridley turtles. In: Plotkin P (ed) Biology and conservation of ridley sea turtles. Johns Hopkins University Press, Baltimore, MD, p 167-189

Wibbels T, Rostal D, Byles R (1998) High pivotal temperature in the sex determination of the olive ridley sea turtle, Lepidochelys olivacea, from Playa Nancite, Costa Rica. Copeia 1998:1086-1088

Wibbels T, Hillis-Starr ZM, Phillips B (1999) Female-biased sex ratios of hatchling hawksbill sea turtles from a Caribbean nesting beach. J Herpetol 33:142-145

Yntema CL, Mrosovsky N (1980) Sexual differentiation in hatchling loggerheads (Caretta caretta) incubated at different controlled temperatures. Herpetologica 36:33-36

Yntema CL, Mrosovsky N (1982) Critical periods and pivotal temperatures for sexual differentiation in loggerhead turtles. Can J Zool 60:1012-1016

Submitted: May 29, 2010; Accepted: September 12, 2012

Proofs received from author(s): November 8, 2012 